\title{
An Analysis of Bone Donor Deferral Rates in Scotland - a 6-Year Study
}

\author{
George Galea
}

Scottish National Blood Transfusion Service, Tissues and Cells Directorate, Edinburgh, UK

\section{Keywords}

Living bone donors - Deferral rates . Tissue donation .

Femoral head

\section{Summary}

Background: The Scottish National Blood Transfusion Service (SNBTS) is the main provider of tissues in Scotland. Tissue collection programmes were established in the mid-1990s, and the range of tissues collected has increased progressively over the years. Methods: Whilst the majority of tissues are obtained from cadaveric donations, bone is collected only from living donors who are usually patients undergoing primary hip replacement surgery (surgical donors). The bone is collected in an operating theatre, and, once stored, no further processing takes place prior to issue. Bone that fails for any reason (quality, microbiology or virological nonnegative result) is discarded. Results: The deferral rate amongst live surgical bone donors in Scotland is around $65 \%$, and it has been slowly and progressively rising from around $55 \%$ over the past few years. This needed investigated, particularly because comparisons with blood donors show that the deferral rate amongst bone donors is more than double that of first-time blood donors (29.7\%). Our processes and systems are standardised, and our cohort of bone bank nurses have all been similarly trained and competency assessed. Moreover our data collection was done in a uniform fashion. It was therefore possible to conduct a 6-year audit on bone donor deferrals. It was found that a history of transfusion $(16 \%)$, history of malignancy $(18 \%)$ and bone quality $(26 \%)$ were the main reasons for bone donor deferrals, accounting for $60 \%$ of all deferrals. Conclusions: When these are taken into account, the residual deferral rates become very similar numerically to blood donors. It is important to note however that there are significant differences between the blood and bone donor cohorts. This study also highlighted some of deferral reasons. Particularly malignancy is a cause of significant numbers of deferrals, and the evidence of transmissibility of malignancy through bone donation is not strong. More robust risk assessments should be undertaken prior to implementing deferral conditions.

\section{KARGER}

Fax +497614520714

Information@Karger.de

www.karger.com (c) 2011 S. Karger GmbH, Freiburg

Accessible online at:

www.karger.com/tmh

\section{Schlüsselwörter}

Lebende Knochenspender · Rückweisungsraten · Gewebespende . Femurkopf

\section{Zusammenfassung}

Hintergrund: Der Scottish National Blood Transfusion Service (SNBTS) ist der Hauptanbieter von Geweben in Schottland. Gewebesammlungsprogramme wurden in den mittleren 1990er Jahren eingeführt, und die Spannbreite an gesammelten Geweben hat über die Jahre ständig zugenommen. Methoden: Während die Mehrzahl der Gewebe von Totspenden stammt, kann Knochen nur von lebenden Spendern erhalten werden; meist sind dies Patienten, die sich einer Hüftoperation mit Austausch des Hüftgelenks unterziehen (chirurgische Spender). Der Knochen wird im Operationsaal gesammelt. Einmal gelagert findet keine weitere Prozessierung vor der Transplantation der Knochenspende statt. Knochengewebe, das aus welchen Gründen auch immer (Qualität, Mikrobiologie, virologisch nichtnegatives Ergebnis) den Anforderungen nicht gerecht wird, wird verworfen. Ergebnisse: Die Rückweisungsrate bei lebenden Knochenspendern in Schottland liegt bei etwa 65\%, sie ist über die vergangenen Jahre von 55\% langsam, aber kontinuierlich auf den aktuellen Wert gestiegen. Dies bedarf einer Untersuchung, besonders weil Vergleiche mit Blutspendern zeigen, dass die Rückweisungsquote bei Knochenspendern mehr als doppelt so hoch ist wie bei Erstblutspendern (29,7\%). Unsere Prozesse und Systeme sind standardisiert, und unsere Gruppe von Knochenbankmitarbeitern ist in ähnlicher Weise trainiert und auf ihre Kompetenz geprüft. Darüber hinaus ist unsere Datensammlung in einheitlicher Weise erfolgt. Daher war es möglich, eine 6-Jahres-Prüfung der Knochenspenderrückweisungen durchzuführen. Dabei zeigte sich, dass eine Transfusionshistorie (16\%), eine Malignität (18\%) und die Knochenqualität (26\%) die Hauptgründe für Knochenspenderrückweisungen waren und zusammen für $60 \%$ der Rückweisungen verantwortlich sind. Schlussfolgerungen: Wenn diese miteinbezogen wurden, war die restliche Rückweisungsrate sehr ähnlich der von Blutspendern. Allerdings ist es wichtig, im Sinn zu behalten, dass sich die Blutund Knochenspenderkohorten signifikant unterscheiden. In dieser Studie werden einige dieser Unterschiede dargestellt. Insbesondere eine bösartige Tumorerkrankung ist ein Grund für eine Vielzahl von Rückweisungen, die Evidenz für Übertragung der Malignität durch Knochenspende ist allerdings nicht stark. Robustere Risikoabschätzungen sollten durchgeführt werden, bevor Rückweisungsbedingungen implementiert werden. 


\section{Introduction}

Since 2000, the Scottish National Blood Transfusion Service (SNBTS) has been the preferred provider of bone and tissues for Scottish patients. Since then it has become a practically monopoly supplier of bone in Scotland. Bone collections, which average about 1,200 bones annually, are only collected from live donors and stored as fresh frozen surgical bone. No disinfection or sterilisation steps are undertaken, therefore the medical history, which is a key process in determining the suitability for bone donation, is crucially important. Transmission of disease by tissues including bone is well documented [1], and it is well known that freezing alone does not remove this risk [2].

Bone in Scotland is collected in major hospitals in 5 Scottish cities (Aberdeen, Dundee, Edinburgh, Glasgow and Inverness), from patients who are undergoing primary hip replacement.

All reasons for deferral are recorded in a standardised fashion and have been in done in the same way for the past several years. Moreover all our nurses follow a similar set of guidelines: The Guidelines for the UK Blood Transfusion Services: the Red Book - 2007 [3] and the associated SNBTS Donor Selection guidelines for live donors (regularly updated).

The aims of this study were fourfold:

- Compare bone donor deferral rates with those of blood donors.

- Identify the main reasons for surgical bone donor deferrals.

- Attempt to identify the quality of the decision making process when a deferral is made.

- Finally it was important to see whether our standardised formats of recording the deferral reasons were comprehensive enough and fit for purpose.

\section{Methods and Results}

Dedicated bone bank nurses who are employed by SNBTS are notified of the patients admitted for this type of operation; they review the patients' medical notes. If there are no clear contra-indications for bone donation a medical interview is conducted, face to face. The format of the interview is standardised using a uniform questionnaire. The nurses are all trained and updated in donor selection guidelines and have regular updates. All their training is recorded, and their com- petency is assessed. Of all deferrals that take place approximately $75 \%$ are done at the stage of reviewing the donors' notes and the rest following the personal interview.

Deferral reasons are recorded in a standardised way (table 1) and have been recorded this way throughout the period of this study. To enable direct comparisons, all data is shown in percentages. However it is important to provide a picture on the actual numbers of bone donors deferred in each Scottish region. A typical year's data is provided in table 2. It is clear that Edinburgh and Glasgow review many more donors than the rest.

\section{Comparisons of Deferral Rates}

As can be seen from figure 1, the deferral rate of surgical bone donors in Scotland is consistently between 55 and $65 \%$ (mean $62.5 \%$ ). If one were to compare this deferral to that of first-time blood donors, which stands at $29.7 \%$ (SNBTS internal donor data), there is a clear difference.

Some of the reasons for bone donor deferrals relate to the quality of the bone itself. Although there are differences between the regional hospitals, the mean deferral rates for bone quality is $22.5-26 \%$ (fig. 2). Therefore a more accurate com-

Table 1. Primary reasons for deferral of potential bone donors

Infection
History of transfusion - definite
History of transfusion - probable
Hepatitis
Travel history including animal bites
History of receipt of organ/tissue
Infection risk e.g. needle stick injury/body piercing
CJD/vCJD risk e.g. brain surgery/familial CJD
Behavioural/social history
Donor
Medication
Systemic autoimmune disease
History of malignancy
Inflammatory arthritis
Dementia/Parkinson/mental illness
Other
Autologous use
Poor quality
Avascular necrosis
Cystic femoral head
Femoral head too small on X-ray
Collapsed femoral head/previous surgery to femoral head
Other

Table 2. Number of donors 2009/2010

\begin{tabular}{lcccccc}
\hline & Aberdeen & Dundee & Edinburgh & Glasgow & Inverness & Total \\
\hline Number of donors reviewed & 342 & 447 & 1,065 & 1,918 & 290 & 4,062 \\
Number of donors acceptable & 94 & 167 & 335 & 494 & 132 & 1,222 \\
$\%$ Acceptable & 27 & 37 & 31 & 26 & 45 & 30 \\
\hline
\end{tabular}


parison with first-time blood donors is to exclude the bonerelated deferrals. This equates to $40 \%(62.5 \%-22.5 \%)$ - still significantly different from blood donors.

\section{Main Deferral Reasons}

Figure 3 is an example of annual main deferral reasons (medical and bone quality) for bone donors.

Two reasons for medical deferrals clearly stand out - a history of blood transfusion (definite and probable) and a history of malignancy. A history of transfusion was introduced as a permanent deferral in 2005-2006 as a vCJD precautionary measure. Initially it was only a definite history of transfusion, followed very soon thereafter with history of probable transfusion (as typified by either a history of major surgery or a major road traffic accident). As figure 4 shows, this deferral

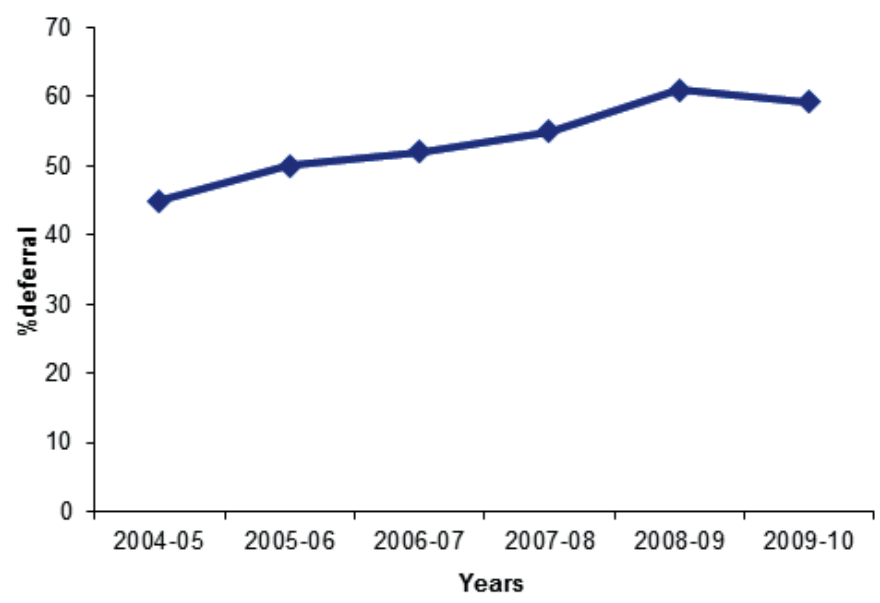

Fig. 1. Deferral rate of surgical bone donors. alone consistently accounts for a deferral of between 15 and $20 \%$. In the context of blood donation a history of transfusion only accounts for $4-7 \%$ of deferrals.

A history of malignancy is also a significant deferral reason amongst bone donors accounting for $15-20 \%$ of deferrals which has been consistent throughout the period of the study. This is illustrated in figure 5 .

If one takes into account these two medical deferral reasons combined, it is clear that they account for the major numerical differences between blood and bone donors. Although the mean Scottish data is important for comparisons, differences exist between the regions and also when analysed by individual nurse (data not shown). This prompted us to investigate further the reasons for such differences.

\section{Quality of the Decision Making Processes}

a) Bone quality issues: The deferral rate in Edinburgh for bone quality issues (defined as in table 1) is significantly higher than in the other regions (by as much as double in some instances). This is due to several reasons. In Edinburgh the bone bank nurse has access to the PACS (Picture Archiving and Communication system) which enables images such as X-rays and scans to be stored electronically and viewed on screens, creating a nearly filmless process and improved diagnosis methods. Such access is not available elsewhere. Moreover in some regions (Dundee and Aberdeen) availability of X-rays and clinical advice is not consistently available at the time of the assessment of the bone prior to surgery. Clearly the quality of the decision making process is bound to be different in view of these operational reasons, and we believe such issues account for the majority of the differences.

Fig. 2. \% Deferrals related to bone quality.

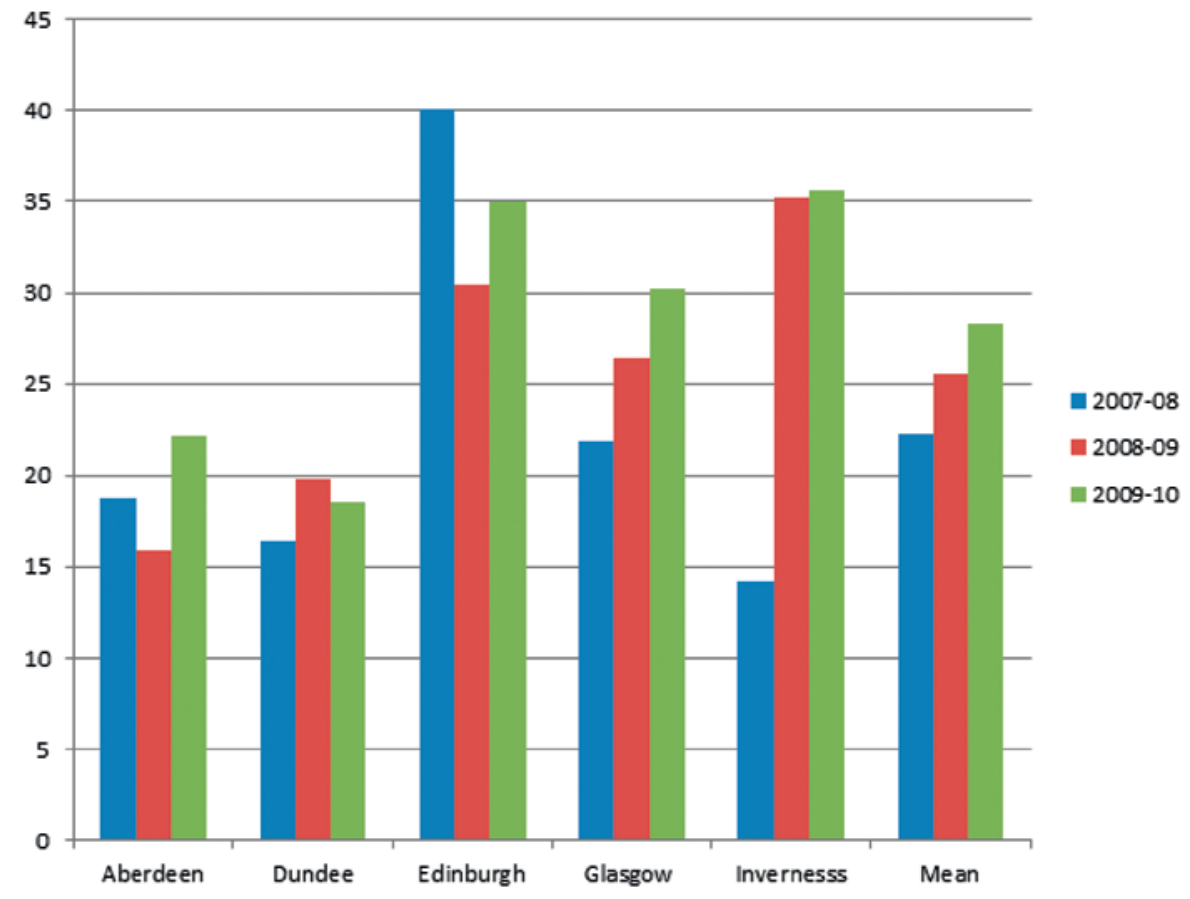




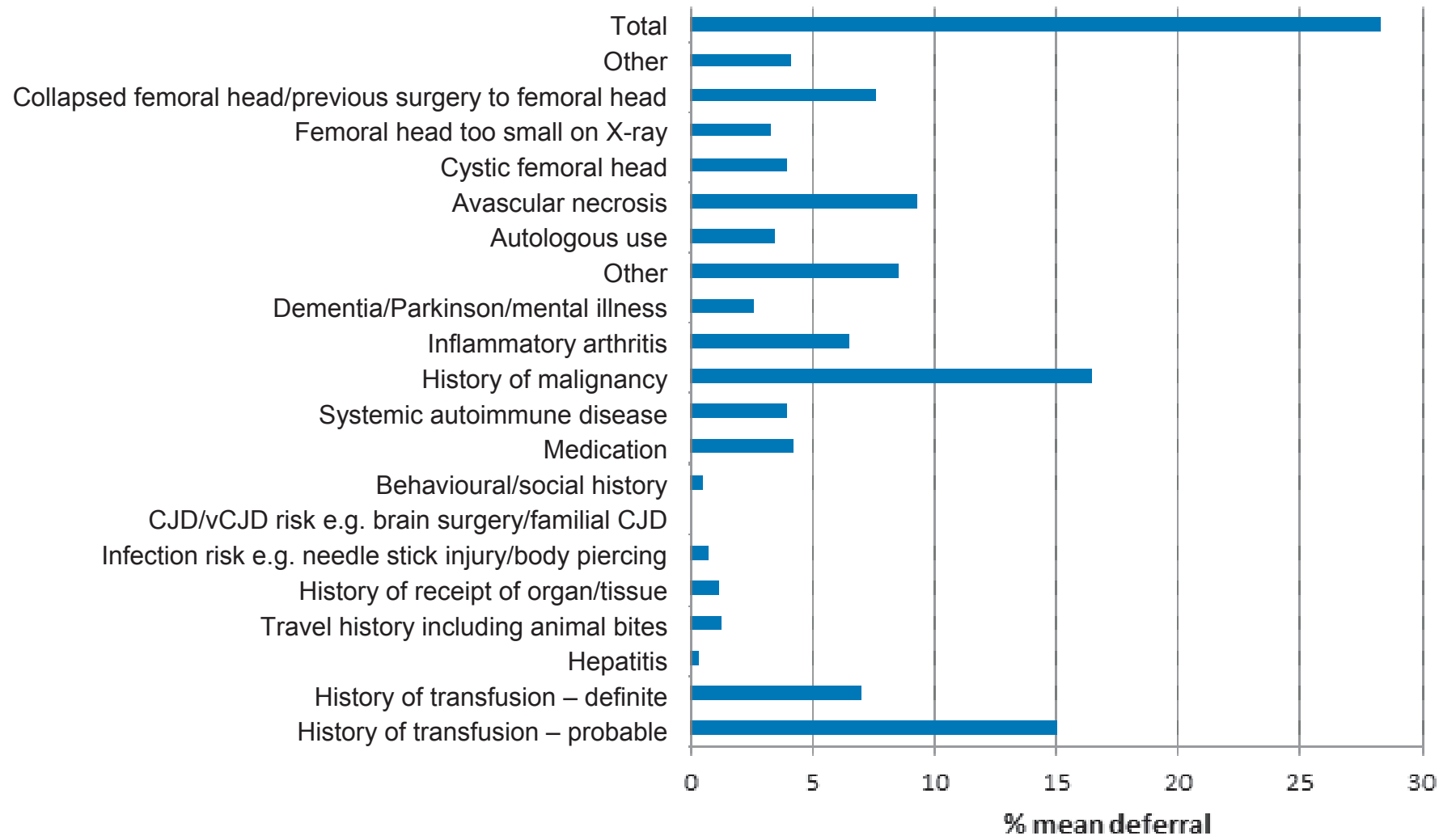

Fig. 3. Main reasons for deferral.

Fig. 4. Transfusion deferrals (\%) - definite and probable.

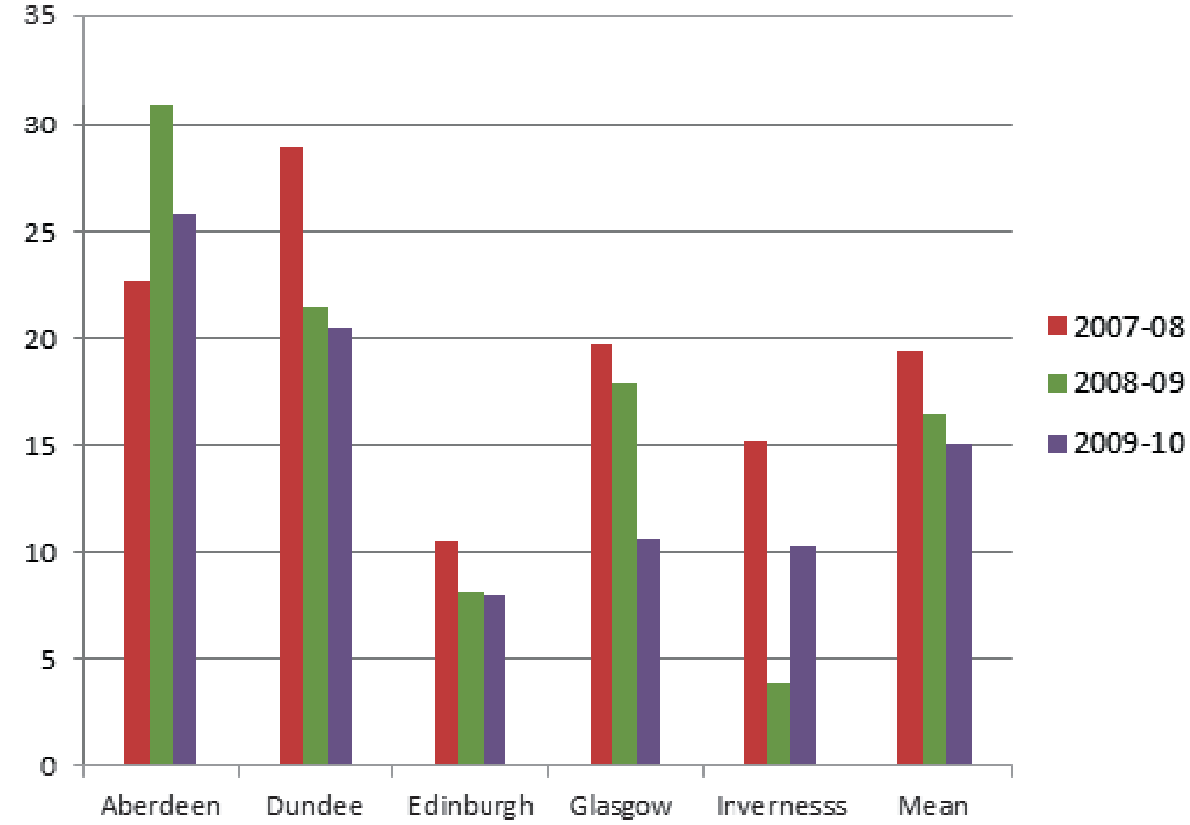

b) History of transfusion: This medical deferral reason is very significant, and again there are regional differences. In Aberdeen and Dundee this deferral is particularly high. In these sites the blood transfusion service also runs the hospital blood bank. Therefore the nurse has access to detailed transfusion records, going back for years on the transfusion history of any patient undergoing total hip replacement. In Glasgow and Edinburgh this is not the case, and the bone bank nurse has to rely on the medical interview and medical records alone to assess whether the patient was previ- 
Fig. 5. Malignancy deferrals (\%).

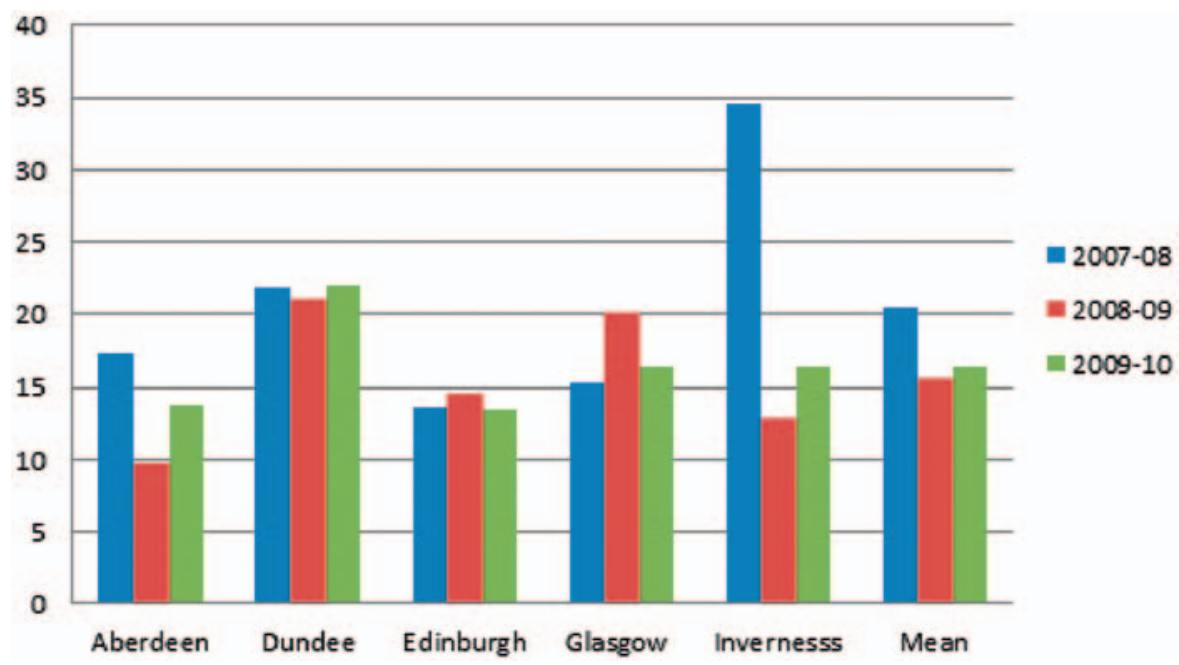

ously transfused. It is well known that transfusion records are not always kept in patients' notes. Moreover our nurses have been inducted in safety, and, wherever there is any doubt about the possibility of transfusion, the tendency is to defer and err on the side of caution.

c) History of maligancy: A history of malignancy is also an important deferral reason. This deferral reason is uniform in all regions. This is to be expected since it relates to the age of the donor population and the fact that malignancy is an important clinical condition that is always recorded on the medical records. The high deferral rate in Inverness in 2007-2008 was thoroughly investigated and was a one off.

\section{Quality of Data Capture}

Most of the deferral reasons, were clearly understood by all and were self-explanatory. However there are a few which were interpreted differently by different nurses. They relate mostly to medication and active systemic disease. If a donor was on medication (which in itself was a deferral reason, e.g. methotraxate) for an active autoimmune systemic disease (e.g. rheumatoid arthritis), some nurses recorded the medication as the primary deferral reason, whilst others recorded the disease. Very occasionally both the medication and the disease were included. Although of no material difference to the deferral data, training sessions took place to establish a standardised way of recording these. It was decided that the primary cause of deferral should be the disease, not the medication. Moreover when a patient had more than one reason for deferral, only the primary one was to be recorded. This ensures that no double counting took place.

\section{Discussion}

This was a 6-year retrospective audit on the deferral of surgical bone donors. This study could only take place because data was collected in a systematic way over a number of years and the process of medical interviewing was also consistent over the period of the study. Moreover, the interviews were conducted by a fixed cohort of nurses who are employed by SNBTS and therefore trained and competency assessed in a very similar way. This made the data consistent.

Initially it was thought that the deferral amongst bone donors was excessively high by comparison to first-time blood donors. It is important to note some key differences between the bone donor and blood donor populations. The age profile is very different, the former with a mean age in the mid-twenties (SNBTS donor data) whilst bone donors' mean age is 67 years. This fact alone accounts for many of the differences noted, i.e., a history of transfusion and a history of malignancy. It is well known that the prevalence of virology markers amongst bone and tissue donors is different, being significantly higher in the bone donor population [4, 5]. Again this is probably related to the age profile of the bone donor cohort. Therefore a thorough medical history with a robust deferral process is essential. This is more so in our case, where all the bones are issued as fresh frozen, without any terminal sterilisation steps.

Exclusion of previously transfused donors was introduced in the UK in 2005-2006 as a vCJD precautionary measure to minimize prion secondary transmissions. Its impact is clearly seen over the next 2-3 years. Wherever the nurses have a doubt, where a serious operation could have resulted in a transfusion, the default position is to defer. Although this may result in some donors being unnecessarily deferred, it is better to err on the side of safety. Bone is not a life-saving graft, and we have sufficient supplies.

It is clear that regional differences in the deferral rates exit. These were analysed in more detail and explanations sought. All our bone bank nurses are based in hospitals. In those hospitals where SNBTS also runs the blood banks, our nurses have complete access to all local transfusion records to enable them to diligently search for a history of transfusion. This explains the higher transfusion deferrals in Aberdeen and Dundee. In some hospitals our nurses also have access to 
clinical input from hospital staff for advice and access to PACS. These explain the higher than average deferrals in Edinburgh in particular.

With an audit of this type, it is not possible to ascertain whether inappropriate acceptance of donors took place, since decisions on accepted donors were not systematically analysed. The only area that we looked at, was in assessing the quality of the bone collected. Whilst some bone collected was smaller than expected, due to difficulties in sizing on X-ray in some regions, we did not find any evidence of inappropriate collections based on quality parameters.

What we feel is an important aspect of this work is the importance of having SNBTS bone bank nurses with the time dedicated to ensuring that the medical history is fully explored, the quality of the collected bone could be assessed prior to collection and consistence of approach was achieved. This audit has confirmed that the way we collect our deferral data is robust. Minor adjustments have been made to ensure better clarity.

In a similar audit carried out by NHSBT in England between 2003 and 2004, very similar data were published [6]. Quality of bone was a reason for deferral in $22 \%$ of cases - a figure very similar to ours $(22.5 \%)$. Malignancy accounted for $20 \%$ of deferrals in the English study - again very similar to our data. Noting the significance of these deferral rates, it is important to question the relevance of malignancy as a deferral condition. Cases of low-grade lymphoma were revealed in retrieved bone allografts [7], and evidence of lymphoma and low-grade chondrosarcoma were found in femoral heads otherwise considered suitable for donation [8]. Whilst transmission of malignancy is well documented, the risk from tissues is remote with only 2 cases ever reported [9]. The Commission Directive 2004/23/EC (10) requires that malignancy be considered a contra-indication to donation. It may be, however, that deferral criteria should be subject to a risk assessment based on evidence of transmissibility. This is particularly so when the criterion is the cause for the deferral of large number of donors.

\section{Acknowledgements}

I would like to thank all the SNBTS bone bank nurses for contributing data to this audit and for openly sharing their data. I would also like to thank all the bone donors who have donated freely their gift for the benefit of others.

\section{Disclosure Statement}

The author declared no conflict of interest.

\section{References}

1 Eastlund T, Strong DM: Infectious disease transmission through tissue transplantation; in Phillips GO, Kearney JN, Strong DM, Von Versen R, Nather A (eds): Advances in Tissue Banking, Vol 7. Singapore, Scientific Publishing Singapore, 2004

2 Sanzen L, Carlsson A: Transmission of human T cell lymphotrophic virus type 1 by a deep frozen bone allograft. Acta Orthop Scand 1997;68:72-74.

3 James V, McClelland B (eds): Guidelines for the Blood Transfusion Services in the United Kingdom, 7th ed 2005. Addendum. London, The Stationary Office, 2007
4 Galea G, Dow B: Comparison of prevalence rates of microbial markers between bone/tissue donors and new blood donors in Scotland. Vox Sang 2006; 91;28-33.

5 Zou S, Dodd RY, Stramer S,L Strong DM: Probability of viraemia with HBV, HCV, HIV and HTLV among tissue donors in the United States. N Eng J Med 2004;351:751-759.

6 Pink F, Warwick RM, Purkis J, Pearson J: Donor exclusion in the national blood services living bone donor programme. Cell Tiss Bank 2006;7;11-21.

7 Sugihara S, Van Ginkel AD, Jiya TU, Van Royen BJ Van Diest PJ Wuisman PIJM: Histopathology of retrieved allografts in the femoral head. J Bone Joint Surg 199981B;336-341.
8 Palmer SH, Gibbons CLMH, Athansou NA: The pathology of bone allograft. J Bone Joint Surg 1999; 81B;333-335

9 Warwick R: Live donors of tissue (chapter 1); in Galea G (ed): Essentials of Tissue Banking. Heidelberg, Springer, 2010, pp 3-21.

10 Commission Directive 2006/17/EC of 8th February 2006 implementing Directive 2004/23/EC of the European Parliament and the Council as regards certain technical requirements for donation, procurement and testing of human tissues and cells. Official Journal of the European Union 2006; L 38/40 09/02/2006. 